\title{
Characterization of interaction of magnetic nanoparticles with breast cancer cells
}

\author{
Macarena Calero ${ }^{1,5 \dagger}$, Michele Chiappi ${ }^{2 \dagger}$, Ana Lazaro-Carrillo ${ }^{1,5}$, María José Rodríquez², Francisco Javier Chichón², \\ Kieran Crosbie-Staunton ${ }^{3}$, Adriele Prina-Mello ${ }^{3,4}$, Yuri Volkov ${ }^{3,4}$, Angeles Villanueva ${ }^{1,5^{*}}$ and José L Carrascosa ${ }^{2,5^{*}}$
}

\begin{abstract}
Background: Different superparamagnetic iron oxide nanoparticles have been tested for their potential use in cancer treatment, as they enter into cells with high effectiveness, do not induce cytotoxicity, and are retained for relatively long periods of time inside the cells. We have analyzed the interaction, internalization and biocompatibility of dimercaptosuccinic acid-coated superparamagnetic iron oxide nanoparticles with an average diameter of $15 \mathrm{~nm}$ and negative surface charge in MCF-7 breast cancer cells.

Results: Cells were incubated with dimercaptosuccinic acid-coated superparamagnetic iron oxide nanoparticles for different time intervals, ranging from 0.5 to $72 \mathrm{~h}$. These nanoparticles showed efficient internalization and relatively slow clearance. Time-dependent uptake studies demonstrated the maximum accumulation of dimercaptosuccinic acid-coated superparamagnetic iron oxide nanoparticles after $24 \mathrm{~h}$ of incubation, and afterwards they were slowly removed from cells. Superparamagnetic iron oxide nanoparticles were internalized by energy dependent endocytosis and localized in endosomes. Transmission electron microscopy studies showed macropinocytosis uptake and clathrin-mediated internalization depending on the nanoparticles aggregate size. MCF-7 cells accumulated these nanoparticles without any significant effect on cell morphology, cytoskeleton organization, cell cycle distribution, reactive oxygen species generation and cell viability, showing a similar behavior to untreated control cells.
\end{abstract}

Conclusions: All these findings indicate that dimercaptosuccinic acid-coated superparamagnetic iron oxide nanoparticles have excellent properties in terms of efficiency and biocompatibility for application to target breast cancer cells.

Keywords: MCF-7 cells, Superparamagnetic iron oxide nanoparticles, Intracellular trafficking, Transmission electron microscopy, Cellular uptake, Endocytosis, Cytotoxicity

\section{Background}

Although huge efforts have led to worldwide advances in cancer treatment, this multifactorial and heterogeneous disease is still one of the major causes of death in developed countries $[1,2]$. In the recent years, several reports have focused on the potential use of superparamagnetic iron oxide nanoparticles (SPION) in cancer research. These reports have raised great expectations because SPION are a promising tool for biomedical applications, including diagnosis by magnetic resonance imaging (MRI)

\footnotetext{
*Correspondence: angeles.villanueva@uam.es; jlcarras@cnb.csic.es

${ }^{\dagger}$ Equal contributors

'Departamento de Biología, Universidad Autónoma de Madrid, Cantoblanco, 28049 Madrid, Spain

2Department of Macromolecular Structure, Centro Nacional de Biotecnología, Consejo Superior de Investigaciones Científicas, 28049 Madrid, Spain

Full list of author information is available at the end of the article
}

and targeted therapy of cancer by hyperthermia and/or releasing anti-cancer molecules, which can be combined in theranostic approaches [3-5].

Factors such as size, shape and surface charge of nanoparticles (NPs) can determine their cellular internalization and distribution and, thus, their effective performance [6,7]. Furthermore, colloidal stability can be achieved, which is essential to ensure reproducibility, as well as to influence the amount of cellular loading and toxicity. The possibility to modify the surface of these particles with biologically active compounds enables transport of therapeutic agents into specific target cells, increasing specificity and avoiding the access of cytotoxic agents to non-target tissues during the delivery process [8]. Different SPION have been tested for potential use in cancer treatment by hyperthermia, as they enter into cells with high effectiveness and without any cytotoxicity, 
and they are retained for relatively long periods of time inside the cells [3]. The evaluation of the potential use of these nanoparticles requires a precise knowledge of surface modified SPION internalization mechanisms at the ultrastructural level and resulting intracellular pathways, as well as on the fate of SPION inside the cells. Factors such as uptake rate and internalization dynamics are the key to understand how an insufficient cellular accumulation of nanoparticles can lead to usage limitations, for example as imaging probes [9].

In the past few years, there has been a great interest in applying nanotechnology for biomedical studies, in particular for diagnostic and therapeutic purposes. However, the possible toxicity of nanoparticles to humans and environment has become a question of absolute priority in Nanomedicine [4-6,10].

In this regard, cell cultures are important first line tools to screen therapeutic efficiency and safety of drugs (nanoparticles included) and provide essential information to understanding cell-nanoparticle interactions, before moving to in vivo analysis [11]. Hence, any new magnetic nanoparticle formulation with potential biomedical applications should be accompanied by a detailed study that ensures both its effectiveness and safety. In this sense, several specific parameters and experimental protocols for assessing nanomaterial toxicity have been developed [10].

We have studied the interaction of dimercaptosuccinic acid-coated superparamagnetic iron oxide nanoparticles (DMSA-SPION) with breast cancer cells (MCF-7) in culture. Monodisperse nanoparticles (around $15 \mathrm{~nm}$ in diameter) with a high saturation magnetization value, were surface modified by meso-2,3-dimercaptosuccinic acid (DMSA) to ensure their dispersion and stability in aqueous buffers and media [12]. Interaction, uptake of the particles $\left(0.05-0.4 \mathrm{mg} \mathrm{ml}^{-1}\right)$, as well as their accumulation and persistence inside cells after prolonged incubation (up to $72 \mathrm{~h}$ ), were assessed by combining optical light and electron microscopy methods. This approach allowed us to correlate the overall cell visualization with the precise localization of SPION inside the cell, their relationship to cell organelles and the analysis of particle shapes and sizes. Furthermore, several cytotoxicity assays, including cell morphology, analysis of cytoskeleton and adhesion proteins, cell cycle distribution, measurement of intracellular reactive oxygen species (ROS) levels and two viability tests, have been carried out to evaluate biocompatibility of these nanoparticles.

\section{Results and discussion}

\section{DMSA-SPION uptake and internalization in cultured cells}

Size, shape and charge of iron oxide nanoparticles, as well as cell type, are important parameters which affect effective internalization of nanoparticles into cells in culture [13-16]. It has been well documented that positively charged magnetic nanoparticles (MNP) showed a higher degree of internalization than neutral and negatively charged MNP due to their effective attachment to negatively charged cell-membrane surface $[3,14,16]$. Although there are somewhat contradictory findings about cytotoxicity levels between positively or negatively charged nanoparticles [3,17-19], the latter ones are favored due to their overall lower toxicity levels.

Incorporation of DMSA-SPION into MCF-7 cells can be followed by bright field microscopy after $24 \mathrm{~h}$ incubation (Figure 1A), where SPION are observed inside living cells, distributed as brown cytoplasmic spots of different sizes, always outside of the nucleus. Similar results have been previously described for iron oxide nanoparticles with different coatings and different sizes in HeLa (human cervical adenocarcinoma) cell line $[3,17]$.

In depth qualitative and quantitative studies on the internalization of DMSA-SPION in MCF-7 cancer cells were performed by both Prussian blue staining and ferrozine-based assay. Figure 1B shows cells incubated with DMSA-SPION for different times $(0.5-72 \mathrm{~h})$ by Prussian blue staining. An increase of intracellular DMSA-SPION accumulation was visualized as blue cytoplasmic granular stain within cells directly correlating with incubation times. However, the uptake of nanoparticles seems to reach a saturation point at $24 \mathrm{~h}$. It is important to note that $100 \%$ cell labeling efficiency (Prussian blue positive staining) was achieved after $12 \mathrm{~h}$ nanoparticles incubation.

These results were confirmed by colorimetric ferrozinebased assay, a widely recognized test to quantify iron in cultured cells [20]. Figure $1 C$ shows intracellular iron concentrations after 24 and $48 \mathrm{~h}$ incubation at $0.4 \mathrm{mg} \mathrm{ml}^{-1}$ DMSA-SPION (20.67 $\mathrm{pg} \mathrm{cell}^{-1}$ and $28 \mathrm{pg} \mathrm{cell}^{-1}$, respectively). There is abundant literature with regard to SPION-labeling efficiency, although results are difficult to compare because the experimental protocols are different (size and surface coating of the SPION, incubation time, concentration, cell line type, etc.). Generally, prolonged incubation times, as well as elevated iron doses enable to reach higher intracellular loading of SPION and increase labeling efficiency [21,22]. However, overexposure to high concentrations of SPION for extended times may cause cytotoxicity [23]. Therefore, sufficient intracellular uptake of nanoparticles for efficient diagnosis and/or treatment must be balanced with their biocompatibility [17]. In this sense, our results with ferrozine assay indicate that DMSA-SPION accumulate effectively (20.67 $\mathrm{pg} \mathrm{cell}^{-1}$ ) within MCF-7 cells. Previously, we had detected $37.1 \mathrm{pg} \mathrm{cell}^{-1}$ (into HeLa cells), after $24 \mathrm{~h}$ of incubation at $0.5 \mathrm{mg} \mathrm{ml}^{-1}$ DMSA magnetic nanoparticles with lower core diameter $(9 \mathrm{~nm})$. The small difference in the amount of accumulated iron could be either due to different of SPION diameters (15 vs $9 \mathrm{~nm}$ ) or to the type of cell line (HeLa vs MCF-7) [17]. Much lower amounts 


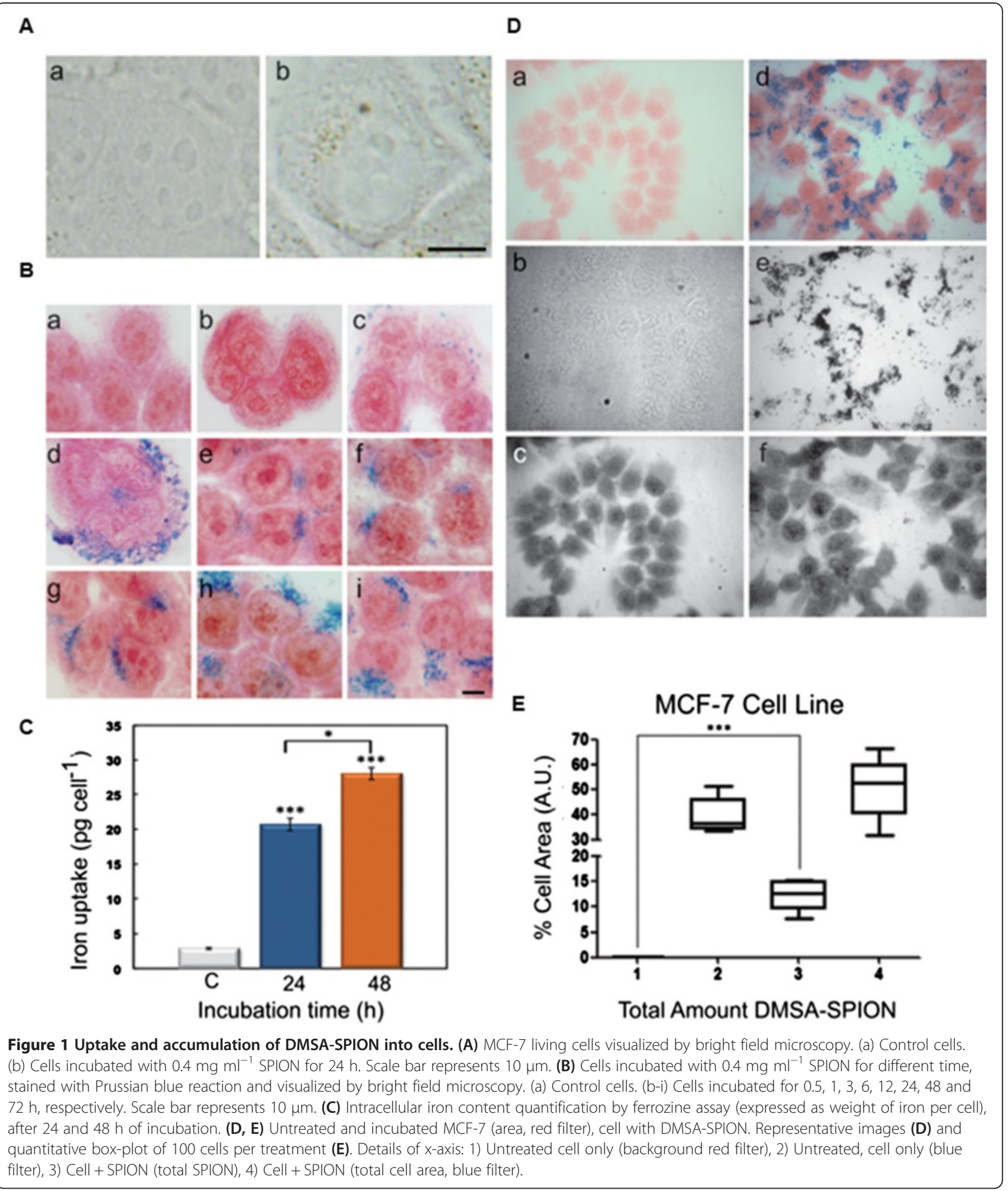

$\left(5.3 \pm 1.1 \mathrm{pg} \mathrm{cell}^{-1}\right)$ have been detected over $48 \mathrm{~h}$ of incubation with SPION (Feridex ${ }^{\circ}$ ) at $0.075 \mathrm{mg} \mathrm{ml}^{-1}$ in labeled NPC (neural progenitor cells) [24].

Quantitative and statistical population analysis of total iron oxide area per total cell area of 100 MCF-7 cells was carried out by automated epifluorescence imaging with multichannel acquisitions (bright field, blue and red channels). From the overlapping and thresholding against the iron content it was possible to identify and quantify the ratio of inorganic iron content versus the total cell 
area. Figure 1D shows representative microscopy images of untreated and exposed MCF-7 cells to $0.4 \mathrm{mg} \mathrm{ml}^{-1}$.

Samples from the same experiments were processed for observation by electron transmission microscopy (Figure 2). Even after very short incubation times $(0.5 \mathrm{~h})$, it was possible to detect SPION clusters within cell cytoplasm (Figure 2a). DMSA-SPION were found surrounded by a membrane and no free cytoplasmatic nanoparticles were detected. Incubations of 1 and $3 \mathrm{~h}$ revealed a small increment in the presence of vesicles containing DMSASPION (Figure 2b, c). During longer incubation times $(6,12$ and $24 \mathrm{~h})$, the number of vesicles with larger DMSA-SPION aggregates increased and they were accumulated close to the nuclei (Figure $2 \mathrm{~d}-\mathrm{f}$ and inset in $\mathrm{f}$ ). Together with an increment in the number of vesicles, prolonged incubation time also resulted in important morphological changes of DMSA-SPION containing vesicles. While analysis of sectioned cells revealed a small increment in their size, the most important change however was related to their morphology, where a clear evolution from translucent vesicles with nanoparticles towards a much denser and multivesicular aspect has been detected (Figure $2 \mathrm{a}-\mathrm{f}$ ).

As MCF-7 cells are derived from a human breast adenocarcinoma, we decided to study also DMSA-SPION uptake and accumulation in a non-malignant breast cell line MCF-10A. Cells were incubated with DMSA-SPION under the same conditions as MCF-7 cells. Analysis by bright field microscopy showed that uptake and accumulation of nanoparticles in MCF-10A cells was equivalent to MCF-7 cancer cells (see Additional file 1). This was confirmed by Prussian blue staining. Analysis by electron microscopy clearly revealed that aggregates of particles were accumulated inside MCF-10A cells near nucleus with similar kinetics to that found in carcinoma cells (Additional file 1). The overall response of these non-cancerous cells was similar to carcinoma cells (see Additional file 1).

Results obtained for nanoparticles internalization in malignant (MCF-7) and non-malignant (MCF-10A) cell lines are not entirely surprising. It is important to recall that all established cell lines, including non-malignant cells, have alterations in their genome, which make them different from healthy cells of an organism. Therefore, MCF-10A cannot be considered as a fully "normal" human cell line $[25,26]$. In this sense, quantum dot (QD) nanoparticles with different surface coatings can be internalized within human mammary non-tumorigenic epithelial cell line MCF-10A as well as in human mammary adenocarcinoma epithelial cell line MCF-7 [27]. Zhang et al. [28] have described that both (MCF-7 and MCF-10A) cells can internalize iron oxide nanoparticles by vesicular transport after incubation for different times (30 min, 4 and $24 \mathrm{~h}$ ). This research was carried out using commercial iron oxide nanoparticles (maghemite $\gamma-\mathrm{Fe}_{2} \mathrm{O}_{3}$ with diameter around $30 \mathrm{~nm}$ ) from Alfa Aesar (Karlsruhe, Germany) without any coating.
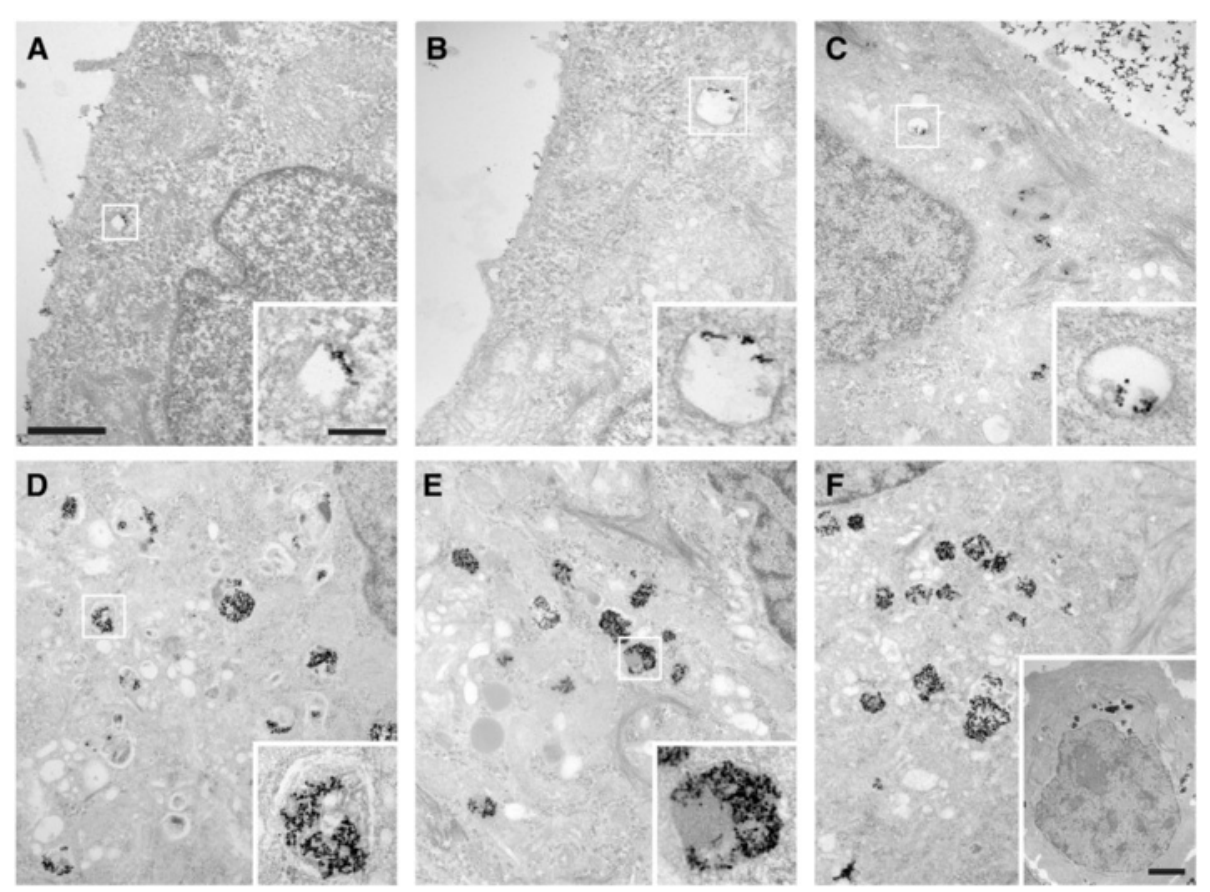

Figure 2 Electron microscopy analysis of uptake kinetics. Images from thin sections of MCF7 cells incubated with DMSA-SPION. (a) Cells incubated for $0.5 \mathrm{~h}$, (b) $1 \mathrm{~h}$, (c) $3 \mathrm{~h}$, (d) 6 h, (e) $12 \mathrm{~h}$ and (f) $24 \mathrm{~h}$. The inset in (f) shows the overall cell shape and morphology. Scale bars represent $1 \mu \mathrm{m}$ for each image, $200 \mathrm{~nm}$ for insets in a to e, and $2 \mu \mathrm{m}$ for the inset in $\mathrm{f}$, respectively. 
In summary, it is rather difficult to compare our results with those reported in the literature previously, because nanoparticles used in other studies have very different characteristics. It is well known that parameters such as nanoparticle size and particle surface coating are crucial on nanoparticle-cell interactions $[3,8,17,29]$.

\section{Internalization mechanism and accumulation of DMSA-SPION inside cells}

To analyze internalization mechanism, cells were incubated with particles at different temperatures. At $4^{\circ} \mathrm{C}$, internalization of DMSA-SPION was inhibited and nanoparticles were attached at the cell surface, while uptake was developed successfully after $3 \mathrm{~h}$ at $37^{\circ} \mathrm{C}$ (Figure $3 \mathrm{~A}$ ). This result indicated that an active energydependent transport was implicated in the SPION internalization process $[13,14,17,21]$.

To get insight into these nanoparticles subcellular localization, MCF-7 cells were incubated with DMSASPION for $24 \mathrm{~h}$ and then incubated with LysoTracker Red to stain the lysosomal compartment and finally visualized by bright field and fluorescence microscopy. Figure 3B show SPION into MCF-7 living cells using fluorescence microscopy. As can be seen in the same figure lysosomes were labeled with LysoTracker Red. Merged images displayed a substantial fraction of red fluorescence from LysoTracker which colocalizes with internalized nanoparticles, strongly suggesting that DMSASPION were accumulated in endosome/lysosome fraction.

To identify the precise mechanism of endocytosis (phagocytosis, pinocytosis, macropinocytosis, clathrinmediated endocytosis, or caveolae-mediated endocytosis), we performed transmission electron microscopy (TEM) studies. The high contrast of the magnetic particles allowed for their clear identification (Figure 4). Small groups of particles were seen near cell membranes. Actually, SPION incubated in culture media present a relatively wide size distribution (ranging between 50 to more than $400 \mathrm{~nm}$, see Additional file 2). Although we did not make an attempt to sort the SPION by size, we found significant differences in the way the SPION were incorporated in the cells according to the aggregate size. Smaller aggregates were seen adjacent to distinct clathrincoated patches (Figure 4A). Closed clathrin vesicles containing small DMSA-SPION aggregates (smaller than 200 $\mathrm{nm}$ ) were seen in the cytoplasm, near membrane. Larger DMSA-SPION aggregates were seen near cell periphery, in most cases engulfed by cell membrane extensions, indicating the existence of a macropinocytic DMSA-SPION uptake process (Figure $4 \mathrm{~B}$ a, b). Other studies have also proposed a macropinocytic process for cationic iron oxide nanoparticles internalization [30], as well as for other nanoparticles [31].

Following short incubation times, particles were found near the cell membrane, showing SPION-containing vesicles closely resembling early endosomes (Figure $4 \mathrm{C}$ a). At later incubation stages, there were denser SPIONcontaining vesicles resembling multi-vesicular bodies containing intraluminal vesicles (Figure $4 \mathrm{C}$ b). Subsequently, the vesicles adopted a multi-lamellar lysosome aspect containing large numbers of DMSA-SPION clusters (Figure 4C c,d).

The same type of analysis has been carried out with the non-malignant MCF10-A cells. The results clearly

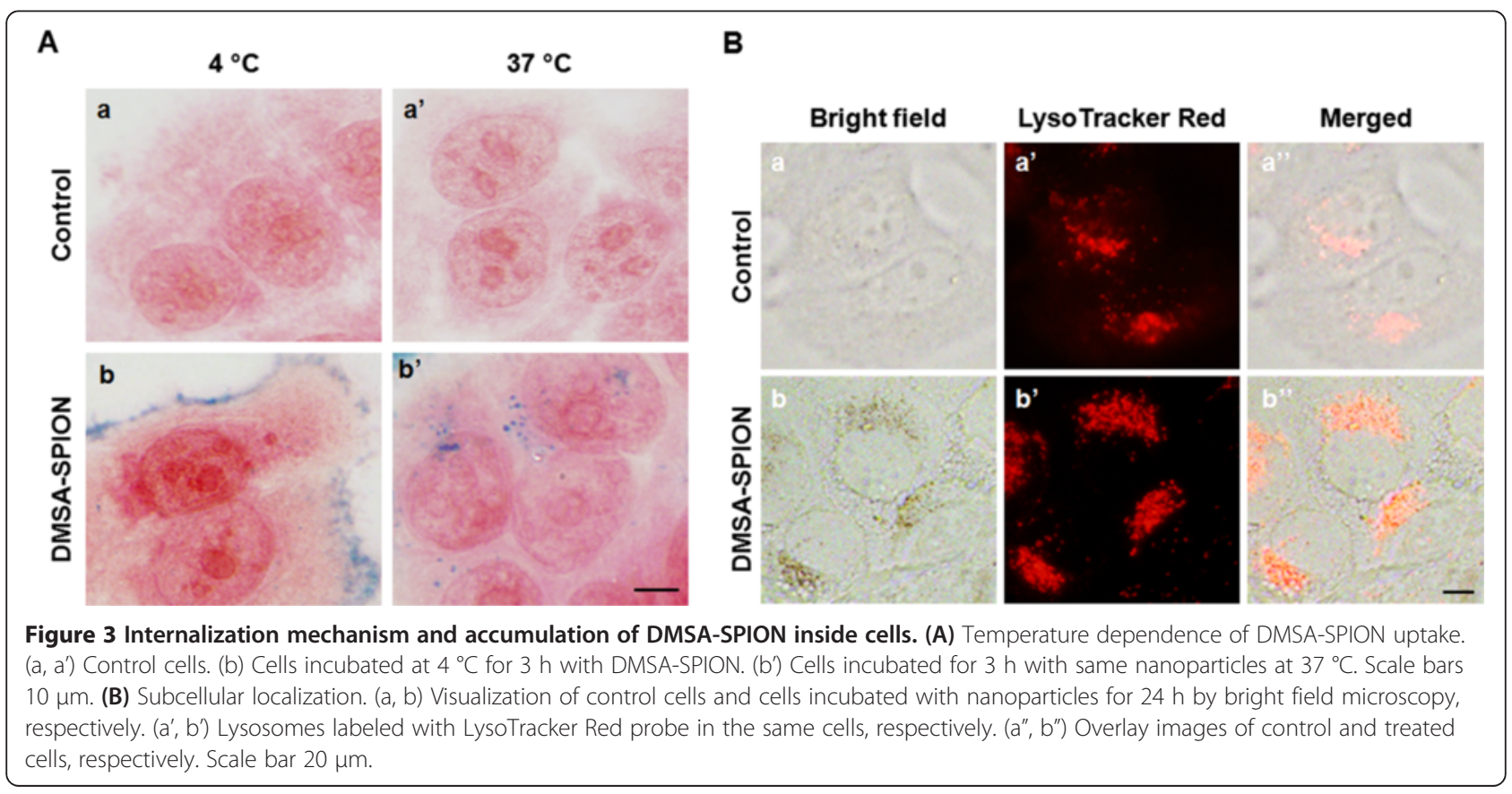




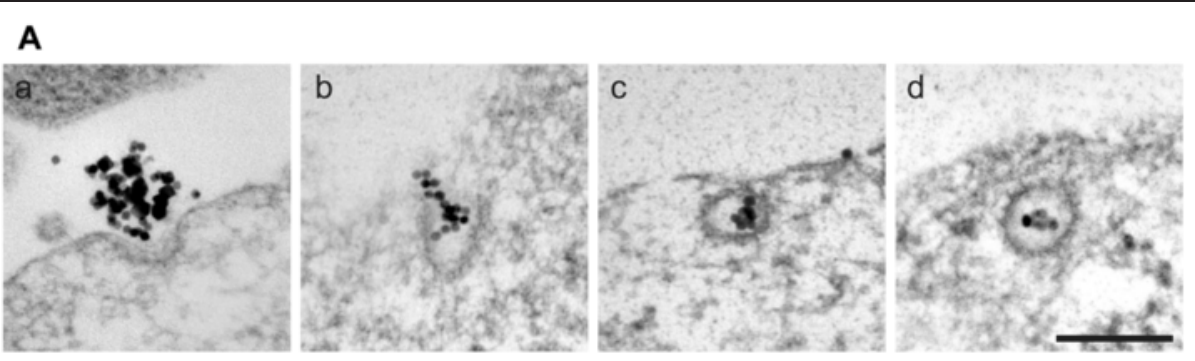

B
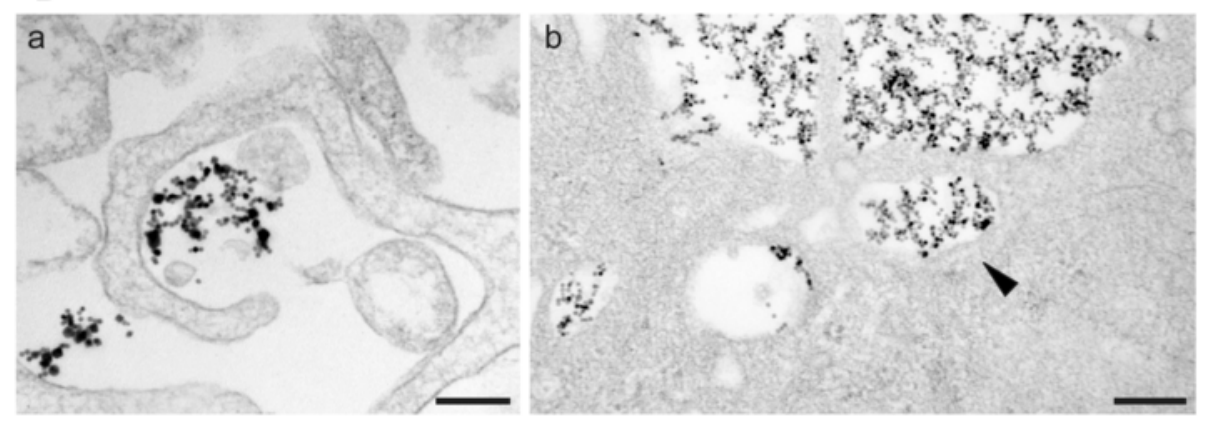

C
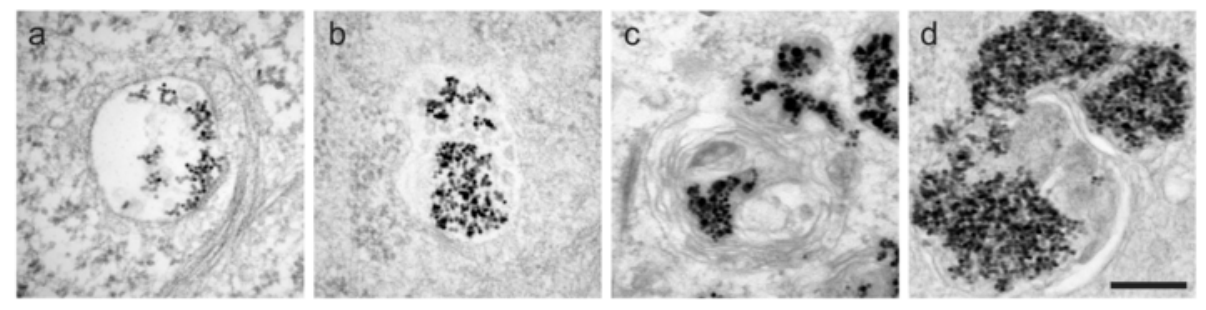

Figure 4 Electron microscopy study of SPION interaction and uptake. (A) Electron microscopy images of thin sections of cells interacting with DMSA-SPION by clathrin mediated uptake ( $<200 \mathrm{~nm}$ in diameter aggregates). Scale bar represents $200 \mathrm{~nm}$. (B) Two images by electron microscopy of thin sections of cells showing typical images of macropinocytosis for DMSA-SPION uptake (>200 nm in diameter aggregates). Scale bars represent $200 \mathrm{~nm}$. (C) Electron microscopy images of different types of endosomes containing SPION aggregates: (a) Early endosome. (b) Multivesicular body containing intraluminal vesicles. (c) Late endosome characterized by a multilamellar morphology. (d) Late endosomes and lysosomes with multivesicular structure and large electron-dense areas. Scale bar represents $200 \mathrm{~nm}$.

showed that incorporation of DMSA-SPION and their intracellular trafficking feature the same overall characteristics in the case of the non-cancerous breast epithelial cells (see Additional file 1).

\section{Intracellular persistence of SPION}

Other important questions related to the incorporation of nanoparticles into cells are to establish how long they remain inside cells and to disclose their eventual release mechanism. To get an insight into these questions, after $24 \mathrm{~h}$ incubation, nanoparticles were removed and cultures were further incubated up to $72 \mathrm{~h}$ at $37^{\circ} \mathrm{C}$. Samples, taken at 24, 48 and $72 \mathrm{~h}$, were stained with Prussian blue and observed by bright field microscopy. Figure 5A shows that SPION remain within MCF-7 cells in vesicles up to $72 \mathrm{~h}$.

To get more detailed information on the evolution of the intracellular vesicles after prolonged incubation times, a parallel analysis to that described above was carried out using electron microscopy. Cells containing DMSA-SPION evolved and divided in a similar way as control cells without DMSA-SPION. Multi-vesicular bodies and lysosomes containing nanoparticles did not change much, even after extended incubation intervals (Figure 5B a-d). SPION clusters were retained inside the vesicles and these vesicles further evolved towards late endosomal or lysosomal morphology, but neither their number nor their localization in cell cytoplasm underwent significant changes, thereby indicating that DMSA-SPION were not massively released from cells. These results suggest that, although cells keep dividing, iron oxide nanoparticles persist inside them for a long time. These qualitative results were confirmed by quantification of intracellular iron content in ferrozine-based assay (Figure 5C), which confirmed that the amount of iron remains substantially unaltered inside the cells after $48 \mathrm{~h}$ post-incubation interval. 

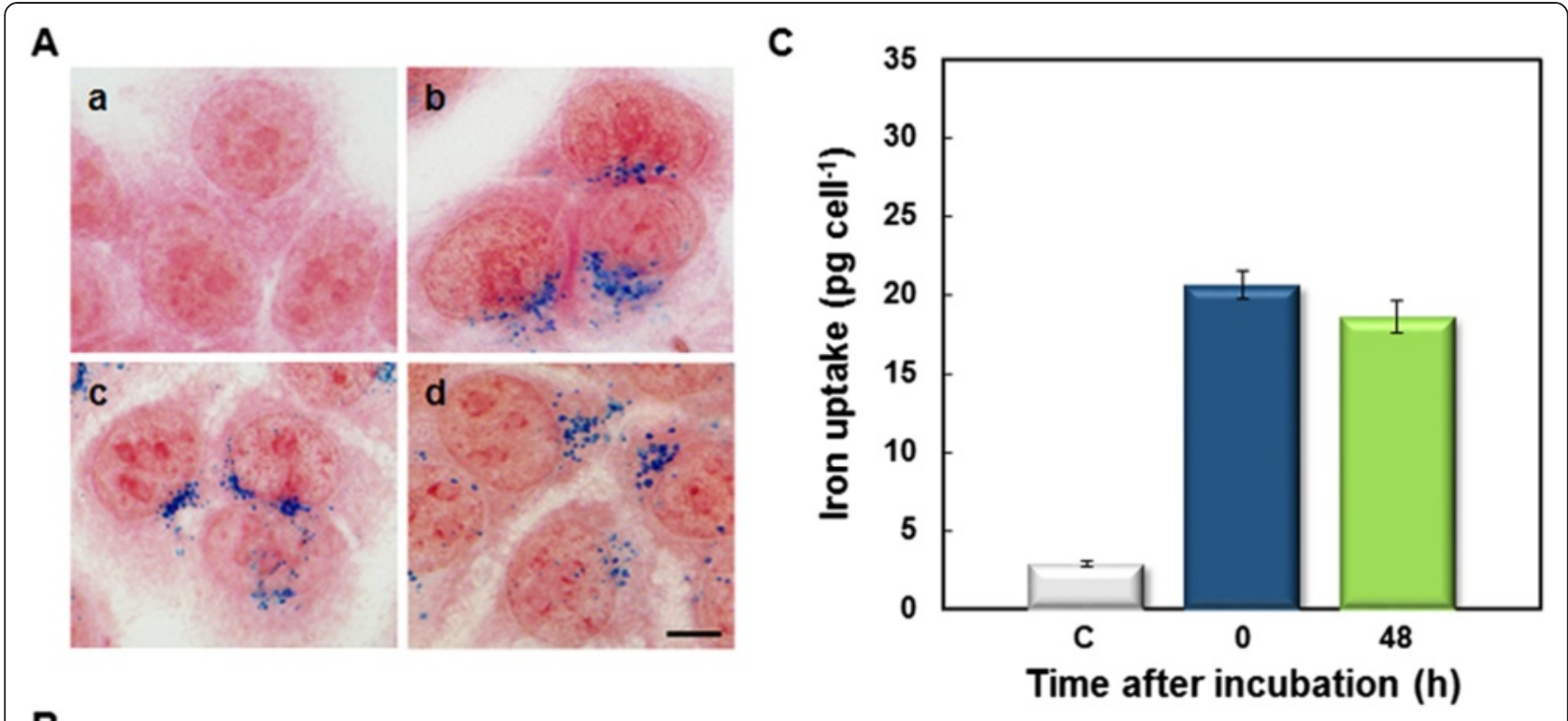

B
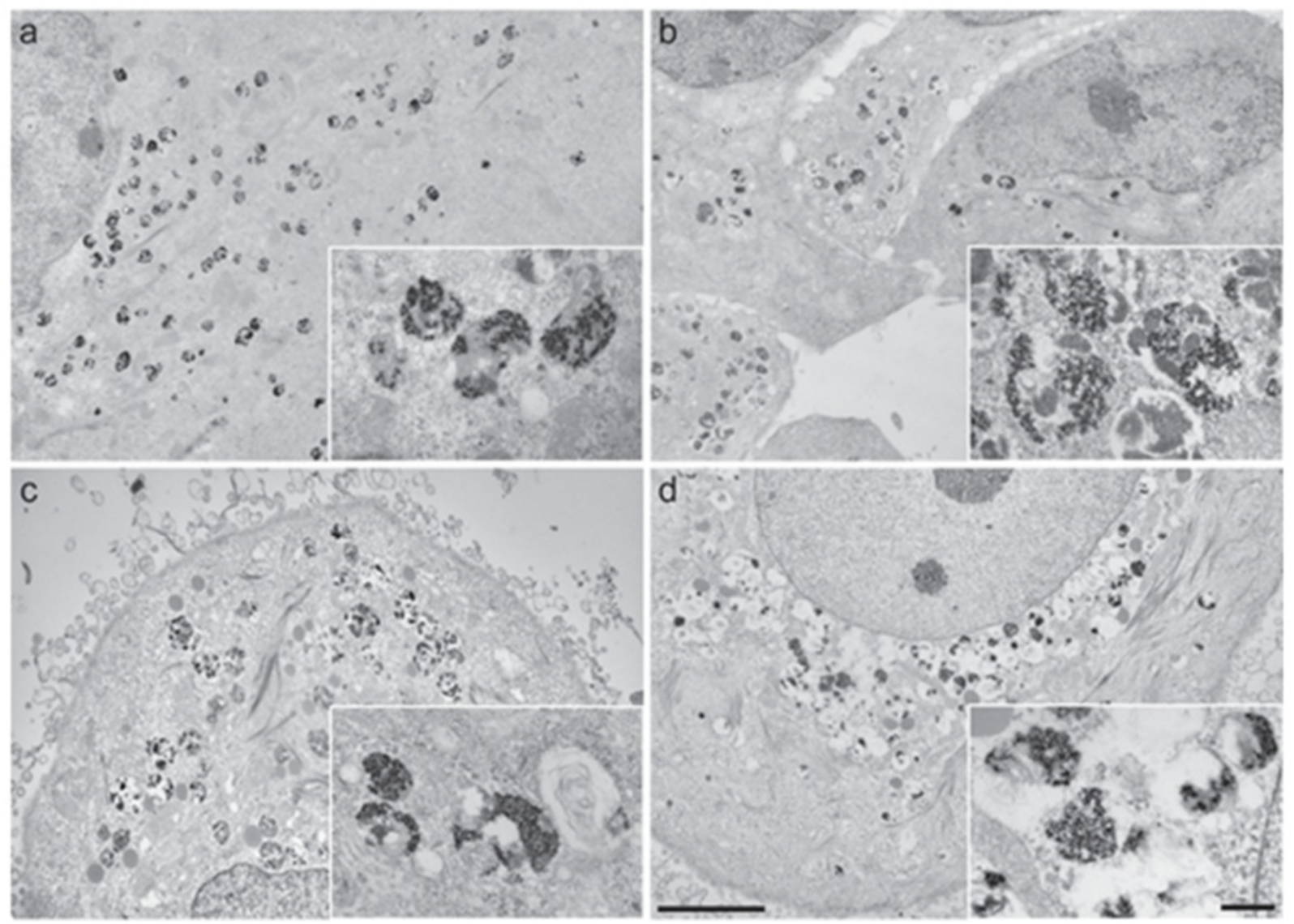

Figure 5 Persistence of internalized DMSA-SPION. (A) MCF-7 cells incubated with nanoparticles for $24 \mathrm{~h}$, stained with Prussian blue reaction after different post-incubation times and visualized by bright field microscopy. (a) Untreated control cells. (b-d) Cells incubated for $24 \mathrm{~h}$ and stained 24, 48 and $72 \mathrm{~h}$ after incubation, respectively. Scale bar represents $10 \mu \mathrm{m}$. (B) Study of persistence by electron microscopy: (a) Cells were incubated with DMSA-SPION for $24 \mathrm{~h}$. The cells were further incubated in medium without particles for additional (b) $24 \mathrm{~h}$, (c) $48 \mathrm{~h}$ and (d) $72 \mathrm{~h}$. Insets show larger magnification details of the endosomes. Scale bars represent $5 \mu \mathrm{m}$ in overall areas and $500 \mathrm{~nm}$ in larger magnification insets, respectively. (C) Intracellular iron content quantification by ferrozine assay (expressed as weight of iron per cell) in control (non-treated) cells (c), and immediately (0) or $48 \mathrm{~h}$ after incubation with DMSA-SPION. 


\section{Cytotoxicity of DMSA-SPION}

Exposure to SPION has been associated with significant toxic effects due to the generation of ROS, which result in deleterious cellular consequences eventually leading to cell death [32-35]. There are contradictory results related to biocompatibility of DMSA-coated magnetic nanoparticles. Several reports have described some cytotoxicity for DMSA magnetic iron oxide nanoparticles in different cell lines $[19,36]$. On the contrary, little effects on cell viability, oxidative stress, cell cycle or apoptosis have been reported for these magnetic nanoparticles by other authors $[17,37]$.

Taking into account such a contradictory background, we decided to analyze the biocompatibility of these nanoparticles using several complementary approaches, such as (i) studies of cytoskeletal components, (ii) cell morphology observations by bright field microscopy (neutral red and Hoechst-33258 staining), (iii) analysis of the cell cycle, (iv) detection of ROS generation and, (v) two alternative viability tests.

\section{(i) Analysis of cytoskeletal components}

Two components of cytoskeleton were analyzed: microtubules (MTs) and actin filaments (F-actin). MTs are highly dynamic fibers of the cytoskeleton, with critical functions in eukaryotic cells including intracellular transport, organization of cell structural dynamics and cell division. We have evaluated the effects of nanoparticle internalization on MTs during interphase and mitosis by means of indirect immunofluorescence analysis to $\alpha$-tubulin (DNA counterstained with Hoechst-33258). Figure 6A shows fluorescence images of MTs (green) and DNA (blue) for interphase and metaphase MCF-7 control cells. After 24, 48 or 72 h of incubation with nanoparticles, interphase microtubules maintain their normal morphology and distribution. In the same samples, DMSA-SPION were visualized inside the cells by bright field microscopy. Distributions of mitotic spindles and chromosomes were also similar to metaphase control cells up to $72 \mathrm{~h}$ after incubation.

We also investigated the effects of SPION on F-actin and vinculin, a protein implicated in cell adhesion as a focal adhesion complex component. F-actin builds the thinnest filaments of cytoskeleton in the cytoplasm of eukaryotic cells. They are involved in cell morphology, transport of vesicles and organelles, positioning of cellular components, cytokinesis, cell motion, cell-cell and cell-substrate interactions, and signal transduction. Focal adhesions are specialized sites containing a complex network of proteins, included vinculin, favoring interactions between cell and extracellular matrix through the actin cytoskeleton [38]. Figure 6B shows fluorescence images of actin microfilaments (red), vinculin protein (green) and DNA (blue) for MCF-7 control cells. Incorporation of DMSA-SPION, followed by localization of them inside the cells by bright field microscopy, did not affect the organization of stress fibers or focal adhesions.

\section{(ii) Cell morphology}

MCF-7 cells were exposed to $24 \mathrm{~h}$ incubation with DMSA-SPION and then they were stained with neutral red or Hoechst-33258 to observe cytoplasmic and nuclear morphology, respectively. Cells stained with neutral red have a similar morphology to control cells after nanoparticle incorporation in cytoplasm and, nuclei also presented the same characteristics as control cells (Figure 7A).

\section{(iii) Cell cycle}

As shown in Figure 7B, cell cycle distribution was not affected after incubation of cells with $0.4 \mathrm{mg} \mathrm{ml}^{-1}$ SPION for $24 \mathrm{~h}$ when compared to untreated control populations. A broad overview of the effects of magnetic and nonmagnetic nanoparticles on the cell life cycle has been recently compiled by Mahmoudi et al. [39].

\section{(iv) Detection of ROS generation}

To analyze whether DMSA-SPION produce ROS, cells were preincubated with SPION for 24, 48 and $72 \mathrm{~h}$ and then treated with the fluorochrome probe DCFH-DA [40]. As shown in Figure 7C, no significant fluorescent signal was detected after $72 \mathrm{~h}$ incubation with SPION at $0.4 \mathrm{mg} \mathrm{ml}^{-1}$. Several in vitro studies have suggested that a range of iron oxide nanoparticles with different physico-chemical characteristics induce ROS formation which can lead to cellular injury and death [32-35].

\section{(v) Cell viability studies}

MTT assay showed that cell viability was not significantly affected by the presence of DMSA-SPION at $24 \mathrm{~h}$ of treatment ( $>96 \%$ viability in relation to the control sample), even at the highest concentration $\left(0.4 \mathrm{mg} \mathrm{ml}^{-1}\right)$ (Figure 7D a). The results obtained using Trypan blue assay (Figure 7D b), confirmed the biocompatibility of DMSA-SPION, and cell survival was $>90 \%$ after $24 \mathrm{~h}$ incubation. It is important to note that Trypan blue exclusion test has been proposed as the gold standard method to validate the cell viability after magnetic nanoparticle incubation [41]. These results were further confirmed using a multiparametric High Content Screening Cytotoxicity Assay in agreement with a previously published report [42], (data not shown).

In summary, the results presented here justify a deeper research on the synthesis and biological characterization of iron oxide nanoparticles. The complementary approaches recommended for risk assessment of nanoparticles [43,44] indicate that DMSA-SPION are safe and efficient nanoparticles for possible biomedical applications. This is a crucial fact, before further functionalization of these SPION for 


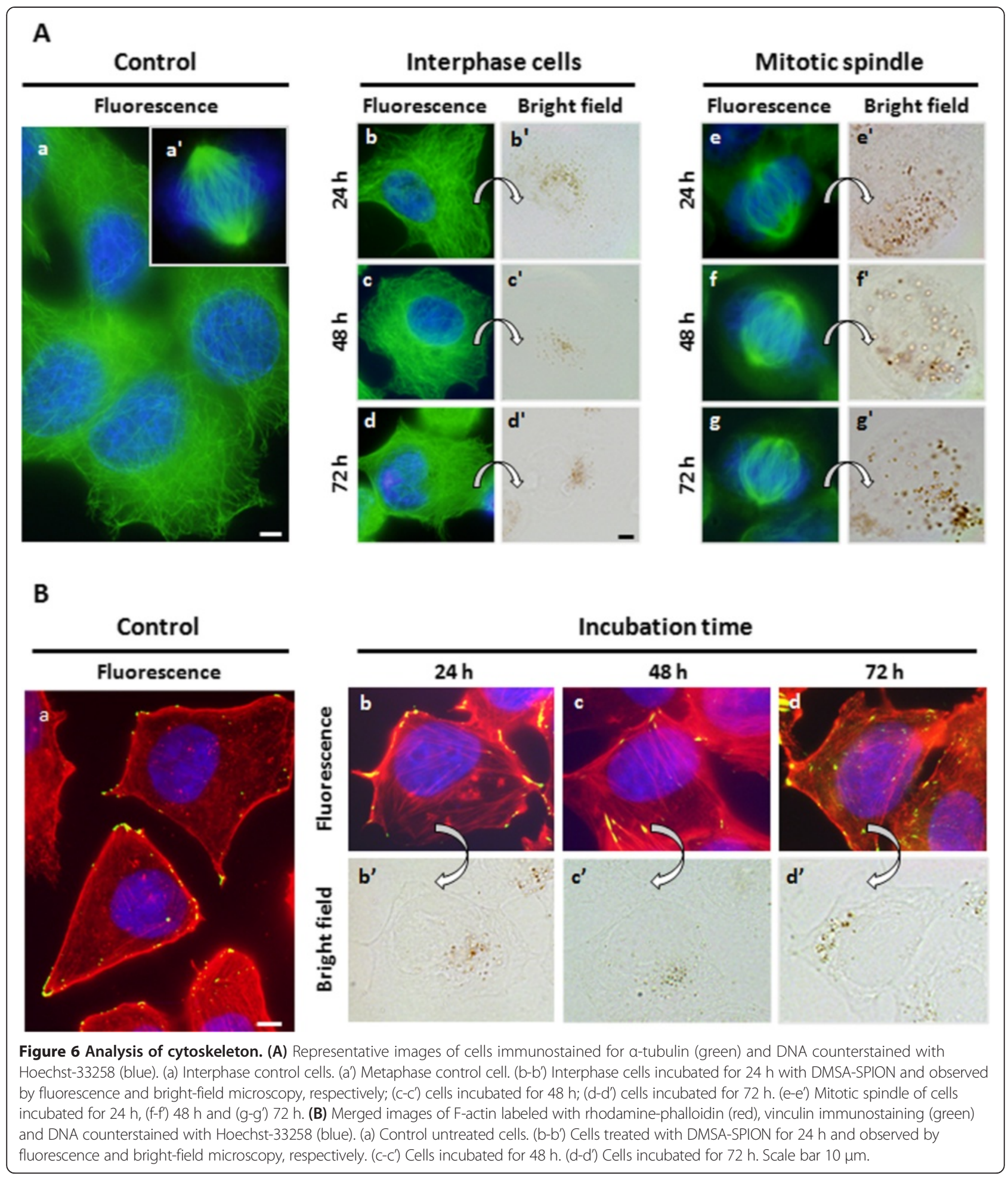

medical applications (drug delivery and/or hyperthermia), that require high levels of intracellular accumulation for effective treatment.

It is important to point out that the purpose of our study was twofold: i) to analyze the effectiveness of DMSA-SPION accumulation within tumor cells and ii) to confirm the absence of toxicity induced by nanoparticles (non-functionalized), to ensure their biocompatibility, even if they were accumulated by non-tumor cells. This is especially important, taking into account the pressing need to identify any potential cellular damage associated with SPION [32]. In the broader context, following such 


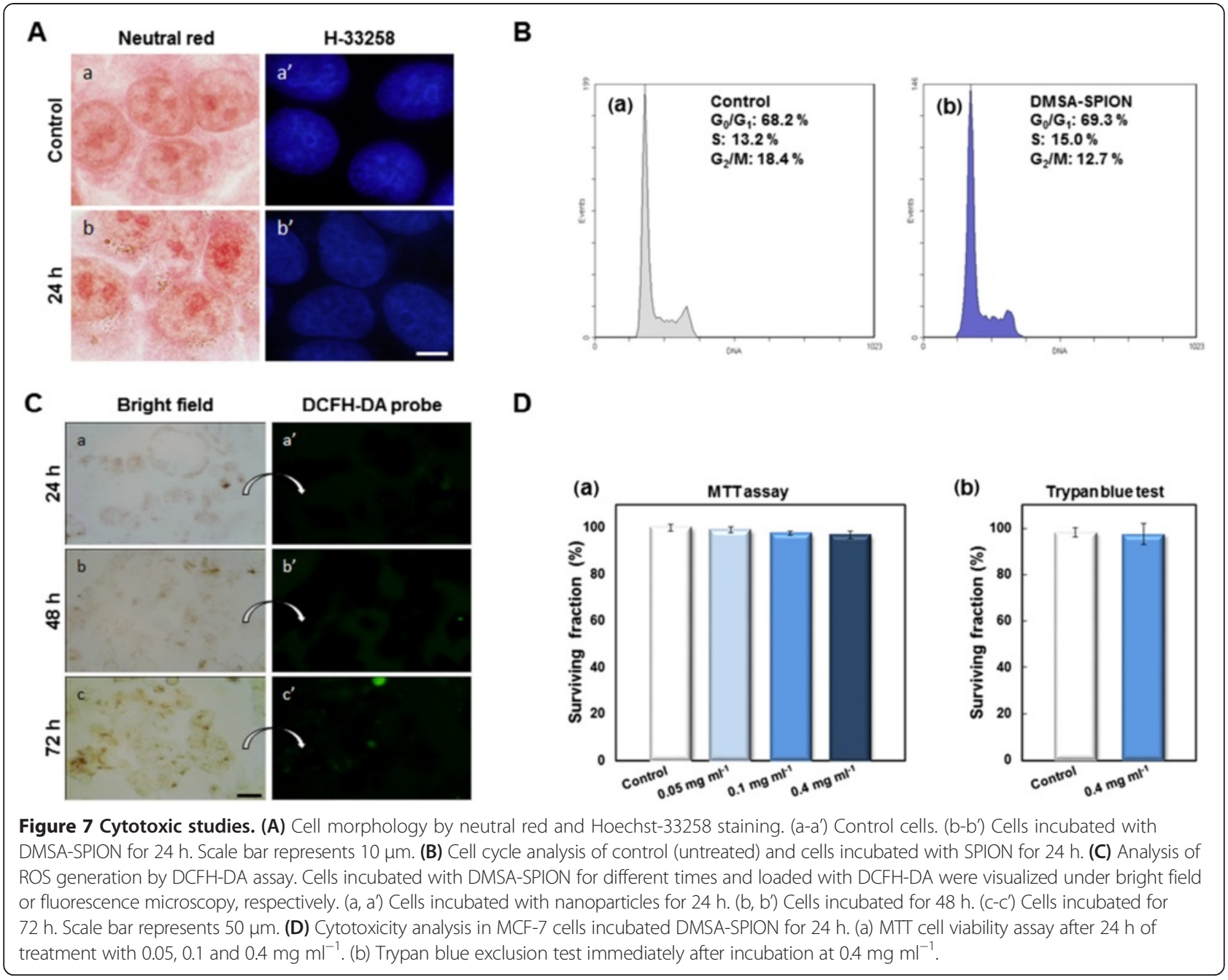

work carried out these "marginally toxic nanoparticles" will be further functionalized with biologically active molecular moieties such as peptides and antibodies for breast cancer targeting. From this prospective, our study is relevant to the safe development of nanoparticles for biomedical applications, as well as to understanding their biological behavior in the "bare" or non-functionalized state, since once delivered inside the cells, nanoparticles can be processed by intracellular pathways (e.g. distinct endocytic pathways) and "stripped" or separated from the molecules they have been originally conjugated with.

\section{Conclusions}

Dimercaptosuccinic acid surface coating of SPION enhanced their cellular uptake efficiency without inducing either cytotoxicity, alteration of the major cytoskeletal components, vinculin protein dynamics, cell cycle or ROS formation in MCF-7 breast cancer cell line. Incorporation of DMSA-SPION inside the cells followed two endocytic pathways depending on the size of the particle aggregates: smaller aggregates were incorporated using a clathrin- dependent path, while larger aggregates were incorporated by macropinocytosis. In all cases, SPION aggregates were found surrounded by endocytotic membrane, which localized in perinuclear areas after long incubation times, but never inside the cell nucleus. Following cellular uptake, SPION showed a slow release rate and continuous persistence over extended intervals inside the cells. These characteristics are relevant for the rational design and subsequent utilization of SPION for biomedical applications, both for diagnosis by magnetic resonance imaging (MRI) and for targeted therapy of cancer by hyperthermia and releasing anti-cancer molecules with significantly reduced side effects.

\section{Methods}

\section{Magnetic nanoparticles}

Superparamagnetic iron oxide nanoparticles of uniform size $(15 \mathrm{~nm})$ were obtained by thermal decomposition of an iron oleate complex in 1-octadecene [12]. These particles, with a coating of DMSA that make them stable in aqueous buffers, were kindly provided by Dr. Puerto 
Morales (ICMM-CSIC) as part of MULTFUN FP7 NMP project (see details in Additional file 2).

DMSA-SPION were sterilized by $0.22 \mu \mathrm{m}$ pore size filtration (Millipore Corp., Bedford, USA). SPION stock at $4 \mathrm{mg} \mathrm{ml}^{-1}$ was dispersed by sonication for $5 \mathrm{~min}$ in a $40 \mathrm{kHz}$ sonicator bath (Branson 3510 ultrasonic cleaner, Thomas Scientific, Swedesboro, USA). SPION were then resuspended in complete cell culture media at a final concentration of $0.4 \mathrm{mg} \mathrm{ml}^{-1}$. The mixture was then sonicated for $1 \mathrm{~min}$ and incubated with cells at different times.

\section{Cell cultures}

Human breast cancer MCF-7 cells were grown as monolayer cultures in Dulbecco's modified Eagle's medium (DMEM), supplemented with $10 \%(\mathrm{v} / \mathrm{v})$ fetal bovine serum (FBS), 50 units $\mathrm{ml}^{-1}$ penicillin and $50 \mu \mathrm{g} \mathrm{ml}^{-1}$ streptomycin. All products were purchased from Gibco (Paisley, Scotland, UK) and sterilized by means of 0.22 $\mu \mathrm{m}$ filters. Cell cultures were grown in an incubator with $5 \% \mathrm{CO}_{2}$ plus $95 \%$ air at $37^{\circ} \mathrm{C}$. Depending on the purpose of experiment, cells were seeded on 24-well plates (with or without $10 \mathrm{~mm}$ square coverslips) or $25 \mathrm{~cm}^{2}$ flasks. Sub-confluent cell cultures were used. All sterile plastics were sourced from Corning (Corning Inc., New York, USA).

Non-tumorigenic human breast epithelial cell line MCF-10A was used for comparison in some experiments (see Supporting Information). Cell lines used in this study were obtained from American Type Culture Collection (ATCC) ${ }^{\circ}$.

\section{DMSA-SPION internalization Live cell imaging}

In order to analyze internalization of nanoparticles, MCF-7 cells were grown on coverslips and incubated for $24 \mathrm{~h}$ with DMSA-SPION. After incubation, culture medium was removed and samples were washed three times with phosphate-buffered saline (PBS, $\mathrm{pH}$ 7.4). Then, cells were observed immediately under bright light microscopy without being processed, to avoid potential fixation artifacts.

\section{Prussian blue staining}

Cells preincubated with nanoparticles for different periods of time $(0.5,1,3,6,12,24,48$ or $72 \mathrm{~h})$, were visualized by Prussian blue staining for iron detection $[17,45]$. Briefly, cells were fixed in methanol (at $-20^{\circ} \mathrm{C}$ ) for $5 \mathrm{~min}$, stained with an equal volume of $4 \%$ hydrochloric acid and $4 \%$ potassium ferrocyanide trihydrate for $15 \mathrm{~min}$, and counterstained with $0.5 \%$ neutral red for 2 min. Preparations were then washed with distilled water, air dried, and mounted in DePeX (Serva, Heidelberg, Germany). All other reagents were purchased from Panreac Química (Montcada i Reixac, Spain).

\section{Quantification of iron in cultured cells Colorimetric ferrozine-based method}

This sensitive assay permits the quantification of iron in cultured cells [46]. In time-dependent studies, MCF-7 cells seeded in 24-well plates were incubated with DMSA-SPION at a fixed concentration of $0.5 \mathrm{mg} \mathrm{ml}^{-1}$ for 24 or $48 \mathrm{~h}$. For intracellular persistence studies, cells were incubated $24 \mathrm{~h}$ and intracellular iron content was evaluated $48 \mathrm{~h}$ after removing DMSA-SPION from culture media by three washes with PBS. After that, in both cases, cells in three wells were trypsinized and cell concentrations per well were determined by hemocytometer with $0.4 \%$ Trypan blue solution. Cells grown in other 24-well dishes were frozen at $-20^{\circ} \mathrm{C}$ for $1 \mathrm{~h}$ and then, $500 \mu \mathrm{l}$ of $50 \mathrm{nM} \mathrm{NaOH}$ (Panreac Química) were added to each well for $2 \mathrm{~h}$ in movement. Aliquots of cell lysates were then transferred to $1.5 \mathrm{ml}$ eppendorf and mixed with $500 \mu \mathrm{l}$ of $10 \mathrm{mM} \mathrm{HCl}$, and $500 \mu \mathrm{l}$ of iron-releasing reagent (a freshly mixed solution of equal volumes of $1.4 \mathrm{M} \mathrm{HCl}$ and $4.5 \%(\mathrm{w} / \mathrm{v}) \mathrm{KMnO}_{4}$ (Merck, Germany) in distilled $\mathrm{H}_{2} \mathrm{O}$. These mixtures were incubated for $2 \mathrm{~h}$ at $60^{\circ} \mathrm{C}$ within a fume hood, since chlorine gas is produced during the reaction. After the mixtures had cooled to room temperature, $150 \mu \mathrm{l}$ of iron-detection reagent (6.5 mM ferrozine (Sigma-Aldrich, St Louis, USA), $6.5 \mathrm{mM}$ neocuproine (Sigma-Aldrich), 2.5 M ammonium acetate (Panreac Química), and $1 \mathrm{M}$ ascorbic acid (Sigma-Aldrich) dissolved in water) were added to each tube. After $30 \mathrm{~min}, 500 \mu \mathrm{l}$ of the solution obtained in each tube was transferred into a well of a 24-well plate, and absorbance was measured at $570 \mathrm{~nm}$ in a SpectraFluor spectrophotometer (Tecan Group Ltd., Männedorf, Switzerland). Iron content of the sample was calculated by comparing its absorbance to that of a range of standard concentrations of equal volume, that had been prepared in a way similar to that of the sample (mixture of $100 \mu \mathrm{l}$ of $\mathrm{FeCl}_{3}$ standards $(0-300$ $\mu \mathrm{M})$ in $10 \mathrm{mM} \mathrm{HCl}, 100 \mu \mathrm{l} 50 \mathrm{mM} \mathrm{NaOH}, 500 \mu \mathrm{l}$ releasing reagent, and $1500 \mu$ detection reagent). The determined intracellular iron concentration for each well of a cell culture was normalized against number of cells per well.

\section{High content screening}

Quantification of iron oxide content was based on automated epifluorescence images taken from stained cell monolayer cultured on slides. On average 100 cells were selected from the two cell line provided. Images were analyzed by single channel, filtered and threshold of each channel was identified. Composite rebuilt in order to identify localization of SPION against cellular staining. Filtering was applied on the red and blue filter in order to account for the SPION or the cell only. 


\section{Endocytic mechanisms}

In order to analyze the degree of involvement of the endocytic mechanisms in internalization of nanoparticles, cells were preincubated with nanoparticles for $3 \mathrm{~h}$ at either $4^{\circ} \mathrm{C}$ or $37^{\circ} \mathrm{C}$, washed three times with $\mathrm{PBS}$, and stained with Prussian blue technique (as described above).

\section{Subcellular localization of nanoparticles}

To determine DMSA-SPION subcellular location inside cells, endocytic compartments of MCF-7 cells were labelled with 50 nM LysoTracker Red DND-99 (Molecular Probes, Eugene, Oregon, USA) fluoroprobe in culture medium, at $37^{\circ} \mathrm{C}$ for $30 \mathrm{~min}$. Cells incubated with nanoparticles for 24 $\mathrm{h}$ were labelled with LysoTraker Red and then coverslips were washed with PBS and cells were observed immediately under bright field and fluorescence microscopy.

\section{Analysis of the cytoskeleton and adhesion proteins Immunofluorescence staining of a-tubulin}

Cells grown on glass coverslips were incubated with nanoparticles for 24, 48 and $72 \mathrm{~h}$ and then, immunostained for $\alpha$-tubulin. Briefly, cells were fixed with cold methanol for $5 \mathrm{~min}$, washed three times for $5 \mathrm{~min}$ with PBS, and then permeabilized with $0.5 \%$ Triton X-100 (Sigma-Aldrich) in PBS for $5 \mathrm{~min}$. After Triton removal, cells were incubated with primary monoclonal mouse anti- $\alpha$-tubulin antibody (Sigma-Aldrich) diluted $1: 100$ at $37^{\circ} \mathrm{C}$ in a wet chamber for $1 \mathrm{~h}$. Three washings with PBS were then carried out before addiction of Triton X-100 for $5 \mathrm{~min}$. Incubation of the secondary antibody (Fab specific goat anti-mouse FITC-IgG; Sigma-Aldrich) was identical to that of the first one. Then, DNA was counterstained by Hoechst-33258 $\left(0.05 \mathrm{mg} \mathrm{ml}^{-1}\right.$ in distilled water) for $5 \mathrm{~min}$. Finally, cells were washed with PBS and mounted with ProLong Gold (Molecular Probes) antifade reagent.

\section{Vinculin immunofluorescence and F-actin staining}

For vinculin immunostaining, cells grown on coverslips were fixed with formaldehyde in PBS $(1: 10 \mathrm{v} / \mathrm{v})$, for 20 $\min$ at $4^{\circ} \mathrm{C}$, washed three times for 5 min with PBS and permeabilized with $0.5 \%$ Triton X-100. After incubation with a blocking solution ( $5 \%$ bovine serum albumin, $5 \%$ FBS, $0.02 \%$ Triton X-100 in PBS) at room temperature for $30 \mathrm{~min}$, cells were incubated with 1:50 solution mouse monoclonal anti-vinculin (Sigma-Aldrich) at $37^{\circ} \mathrm{C}$ in a wet chamber for $1 \mathrm{~h}$. Primary antibody binding was detected using Fab specific goat anti-mouse FITC-IgG diluted 1:50. F-actin was visualized in the same samples by incubation with rhodamine-labeled phalloidin (Sigma-Aldrich) diluted $1: 200$ at $37^{\circ} \mathrm{C}$ in a wet chamber for $25 \mathrm{~min}$. Then, samples were washed three times with PBS, counterstained with Hoechst-33258 for $5 \mathrm{~min}$, washed with PBS and mounted with Prolong Gold antifade reagent.

\section{Cell morphology analysis \\ Neutral red staining}

MCF-7 cells grown on coverslips in 24-well plates were incubated with DMSA-SPION for $24 \mathrm{~h}$, fixed in methanol at $-20^{\circ} \mathrm{C}$ for $5 \mathrm{~min}$ and then stained with $0.5 \%$ neutral red for $2 \mathrm{~min}$. After that, samples were washed with distilled water, air dried, mounted in DePeX and visualized by light microscopy.

\section{Hoechst-33258 staining}

Cells seeded on coverslips and treated with nanoparticles for $24 \mathrm{~h}$ were fixed in methanol at $-20^{\circ} \mathrm{C}$ for $5 \mathrm{~min}$ and stained with Hoechst-33258 for 5 min. Samples were washed with distilled water, air dried, and mounted in DePeX for observation using fluorescence microscopy.

\section{Cell cycle analysis}

MCF-7 cells were plated in $25-\mathrm{cm}^{2}$ flasks and incubated with DMSA-SPION for $24 \mathrm{~h}$. Analysis of cell cycle was performed by flow cytometry using propidium iodide (PI) labeling of DNA cell content. Cells were trypsinized (also harvesting possible detached cells) and centrifuged at $1200 \mathrm{rpm}$ for $5 \mathrm{~min}$. After centrifugation, pellet was resuspended in $100 \mu \mathrm{l}$ of culture medium without phenol red. Then, it was added $50 \mu \mathrm{l}$ of Coulter DNA Prep Reagents Kit (Beckman-Coulter Inc, California, USA), 1 $\mathrm{ml}$ of PI solution with RNase and incubated for $30 \mathrm{~min}$ at $37^{\circ} \mathrm{C}$. Both reagents were purchased from SigmaAldrich. Distribution of cells in different phases of cell cycle was determined using a Coulter Epics XL-MCL flow cytometer (Beckman-Coulter Inc.) with an argon laser line $(488 \mathrm{~nm})$, complemented with appropriate filters, and a minimum of $10^{4}$ labeled cells per sample were analyzed in each experimental condition. Percent of cells in each phase of the cell cycle was compared with that of control cells (without nanoparticles incubation). At least 10000 fluorescent events were counted per sample.

\section{Measurement of intracellular ROS}

Intracellular ROS levels were determined using $2^{\prime}, 7^{\prime}$ dichlorodihydrofluorescein diacetate (DCFH-DA) assay. Cells were seeded on coverslips and, after exposure to nanoparticles for 24, 48 and $72 \mathrm{~h}$, were washed with PBS and incubated with $10 \mu \mathrm{M}$ DCFH-DA (Sigma-Aldrich) for $30 \mathrm{~min}$. Then, cells were washed with PBS again and visualized immediately by fluorescence microscopy. Bright field microscopy was also used to corroborate accumulation of nanoparticles. For control induction of oxidative stress, cells were treated with $800 \mu \mathrm{M} \mathrm{H} \mathrm{H}_{2} \mathrm{O}_{2}$ (Panreac Química) for $1 \mathrm{~h} 30 \mathrm{~min}$ in complete medium. ROS production was observed in cells, $1 \mathrm{~h} 30 \mathrm{~min}$ after that $\mathrm{H}_{2} \mathrm{O}_{2}$ was removed, with $10 \mu \mathrm{M}$ DCFH-DA for $30 \mathrm{~min}$. 


\section{Cytotoxicity assays MTT test}

Cytotoxicity was assessed by MTT colorimetric assay 24 after incubation with DMSA-SPION. Immediately prior to use, a stock solution of dimethylthiazolyl-diphenyltetrazolium bromide (MTT; Sigma-Aldrich, $1 \mathrm{mg} \mathrm{ml}^{-1}$ ) in PBS was prepared. Five hundred microliters of this MTT solution (50 $\mu \mathrm{g} \mathrm{ml} \mathrm{m}^{-1} \mathrm{MTT}$ in culture medium) was added to each culture dish without coverslip. Cells were incubated for $3 \mathrm{~h}$, then reduced formazan was extracted with $500 \mu \mathrm{l}$ dimethylsulfoxide and absorbance measured at $570 \mathrm{~nm}$ in a SpectraFluor spectrophotometer (Tecan Group Ltd, Männedorf, Switzerland). Cell survival was expressed as the percentage of absorption of treated cells in comparison with that of control cells.

\section{Trypan blue exclusion test}

Cell viability was quantified by Trypan blue dye exclusion method. Briefly, after $24 \mathrm{~h}$ of incubation with DMSASPION, trypsin was added to control and treated cells. After cells were detached from the plate, they were resuspended in culture media. Equal volumes of each cell suspension and trypan blue solution $(0.2 \%$ in PBS) were mixed and used for cell counting by hemocytometer. Blue-stained cells were counted as nonviable cells and unstained cells as viable cells.

\section{Bright field and fluorescence microscopy}

Observation of samples processed for bright field and fluorescence microscopy were made with an Olympus BX61 epifluorescence microscope, equipped with an Olympus DP50 digital camera (Olympus, Tokyo, Japan), and processed using the Adobe Photoshop 7 software (Adobe Systems, San Jose, CA, USA). The following filters were used to visualize the fluorescence signal of probes: UV excitation light (365-390 nm) for Hoechst-33258, blue (460-490 nm) for FITC, and green (510-550 nm) for TRITC.

\section{Statistical analysis}

Statistical analysis was performed by GraphPad Prism Software (GraphPad Inc., CA, USA) using one-way ANOVA and Tukey's test. The threshold for significance was $P=0.05$ and $P$ values $<0.05(*),<0.01($ (*) and $<$ 0.005 (\%) were considered as significant.

Sample preparation for transmission electron microscopy MCF-7 cells were incubated with SPION at different times, as described above, washed with PBS and treated with a mixture of $2 \%$ formaldehyde (Ultra Pure EM Grade, Polysciences Inc., Philadelphia, USA) and 2.5\% glutaraldehyde (EM Grade, TAAB Laboratories Equipment Ltd., Berks, UK) in PBS for $1 \mathrm{~h}$ at room temperature. The cell monolayer on the coverslips was then washed with PBS and distilled water, post-fixed for 45 minutes with $1 \%$ osmium tetroxide (TAAB Laboratories Equipment Ltd.) in PBS, washed with distilled water, treated during 45 minutes with $1 \%$ aqueous uranyl acetate (Electron Microscopy Sciences, Hatfield, USA), washed again and dehydrated with growing quantities (50\%, 75\%, 95\% and 100\%) of ethanol seccosolv (Merck KGaA, Darmstadt, Germany). The samples were maintained in coverslips throughout the process and finally embedded in epoxy resin 812 (TAAB Laboratories Equipment Ltd.) contained in gelatine capsules (Electron Microscopy Sciences). The epoxy resin was polymerized for 2 days at $60^{\circ} \mathrm{C}$. Resin was detached from the coverslips by successive immersions in liquid nitrogen and hot water. Ultrathin, 70-nm-thick sections were obtained with an Ultracut UCT ultramicrotome (Leica Microsystems), transferred to 200 mesh Nickel EM grids (Gilder, Lincolnshire, UK) and stained with $3 \%$ aqueous uranyl acetate (10 minutes) and lead citrate (2 minutes) (Electron Microscopy Science). Sections were visualized on a JEOL JEM 1200 EXII electron microscope operating at $100 \mathrm{kV}$ (JEOL Ltd., Tokyo, Japan).

\section{Additional files}

Additional file 1: Uptake, accumulation and cytotoxicity of DMSA-SPION into non oncogenic MCF-10A cells.

Additional file 2: Nanoparticle concentration and stability characterization by Nanoparticle Tracking and Analysis (NTA).

\section{Abbreviations}

SPION: Superparamagnetic iron oxide nanoparticles; DMSA: meso-2,3dimercaptosuccinic acid; DMSA-SPION: Dimercaptosuccinic acid coated superparamagnetic iron oxide nanoparticles; MNP: Magnetic nanoparticles; NP: Nanoparticles; TEM: Transmission electron microscopy; PBS: Phosphate buffered saline buffer; FBS: Fetal bovine serum; DMEM: Dulbecco's modified Eagle's medium; HCl: Hydrochloric acid; MTs: Microtubules; F-Actin: Actin filaments; FITC-lgG: Fluorescein isothiocyanate conjugated immunoglobulin-G; ROS: Reactive oxygen species; DCFH-DA: 2',7'-dichlorodihydrofluorescein diacetate; Pl: Propidium iodide; MRI: Magnetic resonance imaging; MTT: Dimethylthiazolyl-diphenyl-tetrazolium bromide.

\section{Competing interests}

The authors declare that they have no competing interests.

\section{Authors' contributions}

$\mathrm{AV}$ and JLC conceived and designed the study and wrote the manuscript. MC (M Calero) and MCh (M Chiappi) have carried out the majority of experimental techniques and contributed equally to this paper under supervision of AV and JLC respectively. ALC have contributed to cell cycle experiments and ferrozine assay and performed statistical analysis. MJR processed the electron microscopy samples. FJC participated in microscopy and interpretation. KCS, APM and YV completed quantification by High Content Screening, measured DMSA-SPION size in water and culture medium by Nanoparticle Tracking and Analysis (NTA) and partly wrote the manuscript. All authors read and approved the final manuscript.

\section{Acknowledgements}

The research leading to these results have received partial funding from the European Seventh Framework Programme (FP7/2007-2013) under the project MULTIFUN grant agreement no. 262943, and the project Nanofrontmag-CM (S2013/MIT-2850) from the Comunidad de Madrid. Additional grants were obtained from BFU 2011-29038 and CTQ2013-48767-C3-3-R from the Ministerio 
de Economia y Competitividad and S2009/Mat 1507 from the Comunidad de Madrid (to JLC), from EU FP7 project NAMDIATREAM (ref 246479) and from "la Caixa" / CNB International PhD Programme Fellowships. We acknowledge Dr. Puerto Morales and Dr. Gorka Salas for providing the SPION samples. The encouragement and continuous support of Rodolfo Miranda is deeply recognized. Authors recognize the valuable contribution of Carmen Moreno-Ortiz (Flow Cytometry, Centro Nacional de Biotecnología, Madrid).

\section{Author details}

'Departamento de Biología, Universidad Autónoma de Madrid, Cantoblanco, 28049 Madrid, Spain. ${ }^{2}$ Department of Macromolecular Structure, Centro Nacional de Biotecnología, Consejo Superior de Investigaciones Científicas, 28049 Madrid, Spain. ${ }^{3}$ Department of Clinical Medicine, Trinity Centre for Health Science, James's Street, Dublin 8, Ireland. ${ }^{4}$ Centre for Research on Adaptive Nanostructures and Nanodevices (CRANN), and AMBER Centre, Trinity College Dublin, College Green, Dublin 2, Ireland. Instituto Madrileño de Estudios Avanzados en Nanociencia (IMDEA Nanociencia), Cantoblanco, 28049 Madrid, Spain.

Received: 3 October 2014 Accepted: 28 January 2015

Published online: 26 February 2015

\section{References}

1. Lowe KA, Chia VM, Taylor A, O'Malley C, Kelsh M, Mohamed M, et al. An international assessment of ovarian cancer incidence and mortality. Gynecol Oncol. 2013;130:107-14.

2. Walters S, Maringe C, Butler J, Rachet B, Barrett-Lee P, Bergh J, et al. Breast cancer survival and stage at diagnosis in Australia, Canada, Denmark, Norway, Sweden and the UK, 2000-2007: a population-based study. Br J Cancer. 2013;108:1195-208

3. Villanueva A, Canete M, Roca AG, Calero M, Veintemillas-Verdaguer S, Serna CJ, et al. The influence of surface functionalization on the enhanced internalization of magnetic nanoparticles in cancer cells. Nanotechnology. 2009;20:115103.

4. Schroeder A, Heller DA, Winslow MM, Dahlman JE, Pratt GW, Langer R, et al. Treating metastatic cancer with nanotechnology. Nat Rev Cancer. 2011;12:39-50

5. Pollert E, Kaspar P, Zaveta K, Herynek V, Burian M, Jendelova P. Magnetic Nanoparticles for Therapy and Diagnostics. Magnetics, IEEE Transactions on. 2013:49:7-10.

6. Mahmoudi M, Sant S, Wang B, Laurent S, Sen T. Superparamagnetic iron oxide nanoparticles (SPIONs): development, surface modification and applications in chemotherapy. Adv Drug Deliv Rev. 2011;63:24-46.

7. Kralj S, Drofenik M, Makovec D. Controlled surface functionalization of silica-coated magnetic nanoparticles with terminal amino and carboxyl groups. J Nanopart Res. 2011;13:2829-41.

8. Mailander V, Landfester K. Interaction of nanoparticles with cells. Biomacromolecules. 2009;10:2379-400.

9. Huang HC, Chang PY, Chang K, Chen CY, Lin CW, Chen JH, et al. Formulation of novel lipid-coated magnetic nanoparticles as the probe for in vivo imaging. J Biomed Sci. 2009;16:86.

10. Arora S, Rajwade JM, Paknikar KM. Nanotoxicology and in vitro studies: the need of the hour. Toxicol Appl Pharmacol. 2012;258:151-65.

11. Brunner TJ, Wick P, Manser P, Spohn P, Grass RN, Limbach LK, et al. In vitro cytotoxicity of oxide nanoparticles: comparison to asbestos, silica, and the effect of particle solubility. Environ Sci Technol. 2006;40:4374-81.

12. Salas G, Casado C, Teran FJ, Miranda R, Serna CJ, Morales MP. Controlled synthesis of uniform magnetite nanocrystals with high-quality properties for biomedical applications. J Mater Chem. 2012;22:21065-75.

13. Gratton SE, Ropp PA, Pohlhaus PD, Luft JC, Madden VJ, Napier ME, et al. The effect of particle design on cellular internalization pathways. Proc Natl Acad Sci U S A. 2008;105:11613-8.

14. Rejman J, Oberle V, Zuhorn IS, Hoekstra D. Size-dependent internalization of particles via the pathways of clathrin- and caveolae-mediated endocytosis. Biochem J. 2004;377:159-69.

15. Zhu XM, Wang YX, Leung KC, Lee SF, Zhao F, Wang DW, et al. Enhanced cellular uptake of aminosilane-coated superparamagnetic iron oxide nanoparticles in mammalian cell lines. Int J Nanomedicine. 2012;7:953-64.

16. Li Y, Chen Z, Gu N. In vitro biological effects of magnetic nanoparticles. Chin Sci Bull. 2012;57:3972-8.
17. Calero M, Gutierrrez L, Salas G, Luengo Y, Lazaro A, Acedo P, et al. Efficient and safe internalization of magnetic iron oxide nanoparticles: two fundamental requirements for biomedical applications. Nanomedicine. 2014;10:733-43.

18. Liu Y, Wang J. Effects of DMSA-coated Fe3O4 nanoparticles on the transcription of genes related to iron and osmosis homeostasis. Toxicol Sci. 2013;131:521-36.

19. Pisanic 2nd TR, Blackwell JD, Shubayev VI, Finones RR, Jin S. Nanotoxicity of iron oxide nanoparticle internalization in growing neurons. Biomaterials. 2007;28:2572-81.

20. Wang Z, Cuschieri A. Tumour cell labelling by magnetic nanoparticles with determination of intracellular iron content and spatial distribution of the intracellular iron. Int J Mol Sci. 2013;14:9111-25.

21. Gu J, Xu H, Han Y, Dai W, Hao W, Wang C, et al. The internalization pathway, metabolic fate and biological effect of superparamagnetic iron oxide nanoparticles in the macrophage-like RAW264.7 cell. Sci China Life Sci. 2011;54:793-805.

22. Mahajan S, Koul V, Choudhary V, Shishodia G, Bharti AC. Preparation and in vitro evaluation of folate-receptor-targeted SPION-polymer micelle hybrids for MRI contrast enhancement in cancer imaging. Nanotechnology. 2013;24:015603.

23. Naqvi S, Samim M, Abdin M, Ahmed FJ, Maitra A, Prashant C, et al. Concentration-dependent toxicity of iron oxide nanoparticles mediated by increased oxidative stress. Int J Nanomedicine. 2010;5:983-9.

24. Chen CC, Ku MC DMJ, Lai JS, Hueng DY, Chang C. Simple SPION incubation as an efficient intracellular labeling method for tracking neural progenitor cells using MRI. PLoS One. 2013;8:e56125.

25. Kavsan VM, lershov AV, Balynska OV. Immortalized cells and one oncogene in malignant transformation: old insights on new explanation. BMC Cell Biol. 2011;12:23.

26. Fernandez-Cobo M, Holland JF, Pogo BG. Transcription profiles of non-immortalized breast cancer cell lines. BMC Cancer. 2006;6:99.

27. Xiao Y, Forry SP, Gao X, Holbrook RD, Telford WG, Tona A. Dynamics and mechanisms of quantum dot nanoparticle cellular uptake. J Nanobiotechnology. 2010;8:13.

28. Zhang Y, Yang M, Portney NG, Cui D, Budak G, Ozbay E, et al. Zeta potential: a surface electrical characteristic to probe the interaction of nanoparticles with normal and cancer human breast epithelial cells. Biomed Microdevices. 2008;10:321-8.

29. Shang L, Nienhaus K, Nienhaus GU. Engineered nanoparticles interacting with cells: size matters. J Nanobiotechnology. 2014;12:5.

30. Canete M, Soriano J, Villanueva A, Roca AG, Veintemillas S, Serna CJ, et al. The endocytic penetration mechanism of iron oxide magnetic nanoparticles with positively charged cover: a morphological approach. Int J Mol Med. 2010;26:533-9.

31. Verma A, Stellacci F. Effect of surface properties on nanoparticle-cell interactions. Small. 2010;6:12-21.

32. Singh N, Jenkins GJ, Asadi R, Doak S. Potential toxicity of superparamagnetic iron oxide nanoparticles (SPION). Nano Rev. 2010;1:5358.

33. Shubayev VI, Pisanic 2nd TR, Jin S. Magnetic nanoparticles for theragnostics. Adv Drug Deliv Rev. 2009;61:467-77.

34. Liu Y, Li X, Bao S, Lu Z, Li Q, Li CM. Plastic protein microarray to investigate the molecular pathways of magnetic nanoparticle-induced nanotoxicity. Nanotechnology. 2013;24:175501.

35. Hanini A, Schmitt A, Kacem K, Chau F, Ammar S, Gavard J. Evaluation of iron oxide nanoparticle biocompatibility. Int J Nanomedicine. 2011;6:787-94.

36. Ge G, Wu H, Xiong F, Zhang Y, Guo Z, Bian Z, et al. The cytotoxicity evaluation of magnetic iron oxide nanoparticles on human aortic endothelial cells. Nanoscale Res Lett. 2013;8:215.

37. Mejias R, Gutierrez L, Salas G, Perez-Yague S, Zotes TM, Lazaro FJ, et al. Dimercaptosuccinic acid-coated magnetite nanoparticles for magnetically guided in vivo delivery of interferon gamma for cancer immunotherapy. Biomaterials. 2011;32:2938-52.

38. Critchley DR. Focal adhesions - the cytoskeletal connection. Curr Opin Cell Biol. 2000;12:133-9.

39. Mahmoudi M, Azadmanesh K, Shokrgozar MA, Journeay WS, Laurent S. Effect of nanoparticles on the cell life cycle. Chem Rev. 2011;111:3407-32.

40. Wang H, Joseph JA. Quantifying cellular oxidative stress by dichlorofluorescein assay using microplate reader. Free Radic Biol Med. 1999;27:612-6.

41. Hoskins C, Wang L, Cheng WP, Cuschieri A. Dilemmas in the reliable estimation of the in-vitro cell viability in magnetic nanoparticle engineering: which tests and what protocols? Nanoscale Res Lett. 2012;7:77. 
42. Prina-Mello A, Crosbie-Staunton K, Salas G, del Puerto MM, Volkov Y. Multiparametric Toxicity Evaluation of SPIONs by High Content Screening Technique: Identification of Biocompatible Multifunctional Nanoparticles for Nanomedicine. Magnetics, IEEE Transactions on. 2013;49:377-82.

43. Mahmoudi M, Hofmann H, Rothen-Rutishauser B, Petri-Fink A. Assessing the in vitro and in vivo toxicity of superparamagnetic iron oxide nanoparticles. Chem Rev. 2012;112:2323-38.

44. Soenen SJ, De Cuyper M. How to assess cytotoxicity of (iron oxide-based) nanoparticles: a technical note using cationic magnetoliposomes. Contrast Media Mol Imaging. 2011;6:153-64.

45. Cengelli F, Grzyb JA, Montoro A, Hofmann H, Hanessian S, Juillerat-Jeanneret L. Surface-functionalized ultrasmall superparamagnetic nanoparticles as magnetic delivery vectors for camptothecin. ChemMedChem. 2009;4:988-97.

46. Riemer J, Hoepken HH, Czerwinska H, Robinson SR, Dringen R. Colorimetric ferrozine-based assay for the quantitation of iron in cultured cells. Anal Biochem. 2004;331:370-5.

\section{Submit your next manuscript to BioMed Central and take full advantage of:}

- Convenient online submission

- Thorough peer review

- No space constraints or color figure charges

- Immediate publication on acceptance

- Inclusion in PubMed, CAS, Scopus and Google Scholar

- Research which is freely available for redistribution 